S. Fischer, orcid.org/0000-0001-7298-9960
Szechenyi Istvan University, Department of Transport Infrastructure and Water Resources Engineering, Gyor, Hungary, e-mail: fischersz@sze.hu

\title{
INVESTIGATION OF EFFECT OF WATER CONTENT ON RAILWAY GRANULAR SUPPLEMENTARY LAYERS
}

Purpose. To determine the relationship between water content of continuously graded granular supplementary layers for railway substructure and their inner shear resistance and load bearing capacity.

Methodology. Four different 'samples' were produced as standard granular products from andesite. Two of them are common base courses for road construction in Hungary, the other two are common railway supplementary layers. The author performed laboratory measurements (multi-level shear box tests) that are adequate for the evaluation of inner shear resistance. The measurements of load bearing capacity and Proctor tests were executed in the laboratory of Colas Hungaria Ltd. The author performed measurements with the optimal water content values of each sample, as well as lower and higher values than them. This can show how the given granular material is sensible to the change of water content.

Findings. It was proved that the granular supplementary layers, which are standardized products in road construction (as base courses), also seems to be adequate in railway construction; they are not so sensible to the variation of their water content. It does not mean that the other two granular layers are not adequate for railway substructures, but the application of road 'products' have to be considered as substitute products.

Originality. The author tried to emphasize the adequacy of rock mining for construction of ballasted railway tracks, as well as the optimal use of mineral wealth in every country with its results.

Practical value. The obtained results of the present paper can be useful in the area of rock mining, and railway infrastructure engineering. During construction procedures the optimal water content values should be taken into considerations for compaction to be able to reach maximal compactness (density), but too high water content has to be avoided, which is based on the results. They can be also considered in the design phase.

Keywords: ballasted railway tracks, substructure, granular material, inner shear resistance, load bearing capacity

Introduction. Nowadays the mineral wealth is a very important and significant task all over the world. The stone quarries and gravel pits provide the base materials for construction of buildings, transport infrastructural facilities, and so on. There are many researchers who have been dealing with this area. It can be approached from the aspect of aggregates (geophysical and geotechnical point of view, type and quality of rock, and others) [1, 2], as well as the technology of scaling, crushing procedures $[3,4]$, transportation inside and outside of the quarries (machines, vehicles) [5-7], mechanization, as well as environmental protection [8], and so on.

The topic of the present article is related to railway infrastructure. In the past 15-17 years more and more railway lines have been rehabilitated and reconstructed in Hungary thanks to the support of the European Union, this support was higher than 6 billion EUR [9]. For example, approximately 3.3 billion EUR was related to the financing period of 2014-2020 from the Integrated Transport OP project [9]. This project had the following details (not only upgrading of railway infrastructure): ders;

- building almost $240 \mathrm{~km}$ of the highway to reach the bor-

- improving travel times on railways, upgrading approximately $280 \mathrm{~km}$ of the railway line;

- decreasing navigation accidents on the Danube compared to the current annual 75 ;

- building and upgrading $132 \mathrm{~km}$ of the metro, tram and local train lines.

The biggest and heaviest part of the railway permanent way's superstructure is the railway ballast bed. It is well known that it consists of crushed stone material according to the related standards. Next to the railway ballast, the upper layers of the substructure are so called supplementary layers with more functions (protection, separation, reinforcement, filtration if needed). These layers are also produced, mixed from granular mineral materials, i.e. mainly from crushed rocks, stones $[10,11]$.

Of course, not only the railway permanent ways need a lot of 'base materials' - as mentioned earlier. The adequate qual-

(c) Fischer S., 2021 ity of crushed stone materials in needed quantity has to be provided so that it is possible to construct a significant length of transport infrastructural facilities. The countries should try to use their own minerals, because the import of this kind of product can be very expensive due to high transportation costs. In this way, the specific national regulations are recommended to be in accordance with the national mineral wealth, the local opportunities, and so on. It means that the optimal costs of production, transportation, incorporation (construction, building-in) have to be considered, as well as the quality of the prepared facilities have to meet the requirements of international and national standards and regulations regarding the planned speed, axle load and proposed traffic of the railway lines, roads, and the others.

Improvement of railway tracks is also important in the $21^{s t}$ century. Some of developments are worth mentioning: ensuring decreased stress in the track and beneath parts that guarantee lower deformation; technologies that provide special work procedure, method, e.g. side tamping that does not disturb the density of ballast layer below the sleepers [12]; developing methods and techniques to provide lower dynamic impacts that can cause supplementary track defects (cracks, breakage, etc.); reducing the wear of rails and other parts of the track [13]; and so on.

Unsolved aspects of the problem. Hungary is relatively rich in adequate quality mineral wealth. There are a lot of stone quarries in the country, mainly in the North, North-East, middle and South parts [14]. In the most quantity Hungary has limestone, dolomite, andesite, and limited quantity of basalt and granite. In the aspect of railway ballast, the main applied materials are basalt and andesite; in case of granular supplementary layers andesite, limestone and dolomite are preferred.

There is a national regulation [11] that was prepared based on the German prescription [10] in 2014 by Hungarian State Railways (MÁV), and it was upgraded in 2020. This regulation is the official railway substructure regulation in Hungary. This document contains chapters related to the supplementary layers of the substructure where two main categories are differentiated:

a) railway lines with design speeds equal to or higher than $120 \mathrm{~km} / \mathrm{h}$; 
b) railway lines with design speeds lower than $120 \mathrm{~km} / \mathrm{h}$.

In category 'A' two products can be applied, CGM1 and CGM2. CGM means coarse grain mixture (in the original German regulation, Ril. 836 [10], their names are KG, i.e. 'Korngemisch'). CGM1 is a quasi-water sealing, CGM2 is a quasi-water pervious layer.

It is a research possibility to investigate several alternate granular materials as protection layers for railway tracks. Primer mining products, e.g. M (mechanical stabilization) and CSBCG materials (crushed stone base layers with continuous grading), can also be adequate for this task. According to the Hungarian e-UT 06.03.52 specification [15], there are several optional products: M22, M56 and M80; as well as CSBCGs: CSBCG 0/22, 0/32, 0/56. It has to be mentioned that $\mathrm{M}$ and CSBCG layers are principally related and prescribed for road base courses, not railway supplementary layers.

M22 product can be an alternative material for CGM1, as well as CSBCG 0/32 for CGM2. The basis of this idea can be explained by Table 1 . It can be seen in Table 1 that the functions of the road base courses and railway supplementary layers are almost the same, this can be also interpreted with Fig. 1. It means the products seem to be exchangeable with each other. Of course, in case water sealing property is required, the alternate product has also to fulfil this requirement; if water permeability is needed, this characteristic should be guaranteed. In this paper laboratory tests of selected four types of supplementary layers are summarized, these tests are not only common tests used (standardized), but special multilevel shear box tests [16]. The testing was performed with different water content values to make it possible to assess the behavior of the materials related to different incorporation, and installation circumstances.

In some cases, M and CSBCG layers can be cheaper than the CGMs due to the mixing and additional transportation costs of CGM layers. The financial aspect of this application is not considered in the current article.

Purpose. The aim of this paper is to compare the mechanical characteristics of CGM layers, as well as M and CSBCG layers; i.e. the investigation of optional application of last two products as railway supplementary layers.

Methods. The author applied the following methods for his research:

- Proctor tests [18];

- measurements of load bearing capacity according to the California Bearing Ratio [19];

- multi-level shear box tests [16].

The Proctor tests were used to be able to determine the optimal water content of the examined granular supplementary layers. This test procedure is a standardized test. The value of optimal water content was important for the further measurements and investigations.

The CBR tests were executed not as usual. These measurements contained the determination of CBR values with stages with different water content values that were in accordance with the previously performed Proctor tests, i. e. with the optimal water content.

The multi-level shear box tests (Fig. 2) were fulfilled based on the concept published Fischer's [16]. Because of the limit-
Requirements for railway and road supplementary (base) layers [11, 17]

\begin{tabular}{|l|l|}
\hline \multicolumn{1}{|c|}{$\begin{array}{c}\text { Functions of railway } \\
\text { supplementary layers }\end{array}$} & \multicolumn{1}{|c|}{ Functions of road base courses } \\
\hline $\begin{array}{l}\text { 1. Uniform distribution of } \\
\text { loads }\end{array}$ & 1. Effective load distribution \\
\hline $\begin{array}{l}\text { 2. Reduction of settlements } \\
\text { during loading }\end{array}$ & $\begin{array}{l}\text { 2. It has to ensure adequate load } \\
\text { bearing capacity }\end{array}$ \\
\hline 3. Separation of layers & $\begin{array}{l}\text { 3. Avoiding harmful } \\
\text { post-compaction during traffic }\end{array}$ \\
\hline $\begin{array}{l}\text { 4. Protection of substructure } \\
\text { against rainwater (precipitation) }\end{array}$ & $\begin{array}{l}\text { 4. It should be adequate plate } \\
\text { and have uniform surface }\end{array}$ \\
\hline 5. Dewatering & $\begin{array}{l}\text { 5. It must not be water and frost } \\
\text { sensitive }\end{array}$ \\
\hline 6. Filtration & $\begin{array}{l}\text { 6. It must not cause cracking in } \\
\text { the asphalt layer (pavement) above }\end{array}$ \\
\hline $\begin{array}{l}\text { 7. Reinforcement of load } \\
\text { bearing layer structure }\end{array}$ & $\begin{array}{l}\text { 7. It should ensure the } \\
\text { construction traffic "flow" as an } \\
\text { adequate "road" }\end{array}$ \\
\hline 8. Frost protection & 8. Economy \\
\hline 9. Reduction of vibration & $\begin{array}{l}\text { 9. Its lifetime should be in } \\
\text { accordance with the planned as } \\
\text { the related prognosis }\end{array}$ \\
\hline
\end{tabular}

ed space the whole test and the test procedure are not detailed in this current paper. The $E_{2}$ static plate load bearing capacity was considered to be $7.2 \mathrm{MPa}$, which was ensured by thickness of $50 \mathrm{~cm}$ XPS sheets. $F_{V}$ vertical loading, loading plate, as well as geogrid layer were not applied during the tests. In every test series the measurements were carried out with shearing at all of the shearing planes from top to down. The result of these tests are the inner shear force values as a function of the vertical distance measured from the shearing plane No. 1. As a boundary condition the inner shear resistance of the sample on the top surface is considered as 0 value.

It has to be mentioned that the Proctor tests and the CBR tests were performed in the laboratory of Colas Hungaria Ltd, hence the multi-level shear box tests were carried out in at Szechenyi Istvan University, Gyor, Hungary.

After the optimal water content values had been defined with the help of the Proctor tests, the samples for CBR and multi-level shear box tests were made ready. The CBR tests were carried out with $5-11 \%$ water content with $2 \%$ steps; the multi-lever shear box tests were completed with three stages of water content: the optimal water content value related to the given sample, and some percentage lower, as well as higher than the optimal one.

The variation of the water content is able to ensure the assessment of their sensitivity in the aspect of load bearing capacity and inner shear resistance.

Properties of the examined granular materials. In this paper four different types of granular supplementary layers were tested:
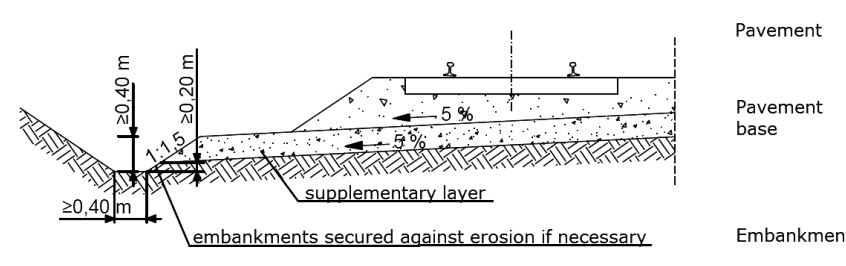

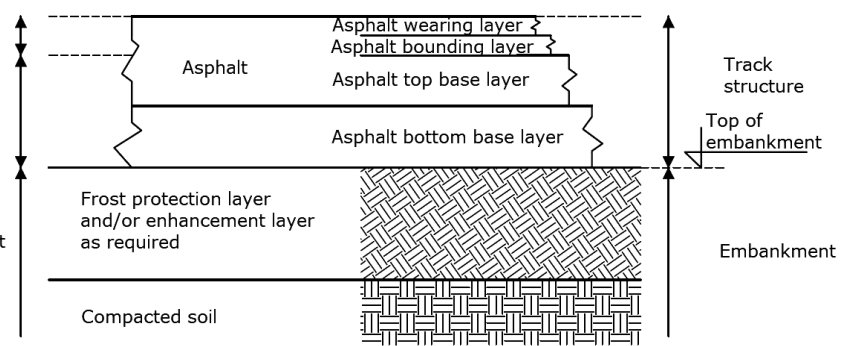

Fig. 1. Cross-sectional set-up of ballasted railway track and asphalt pavement on embankments [11, 17] 


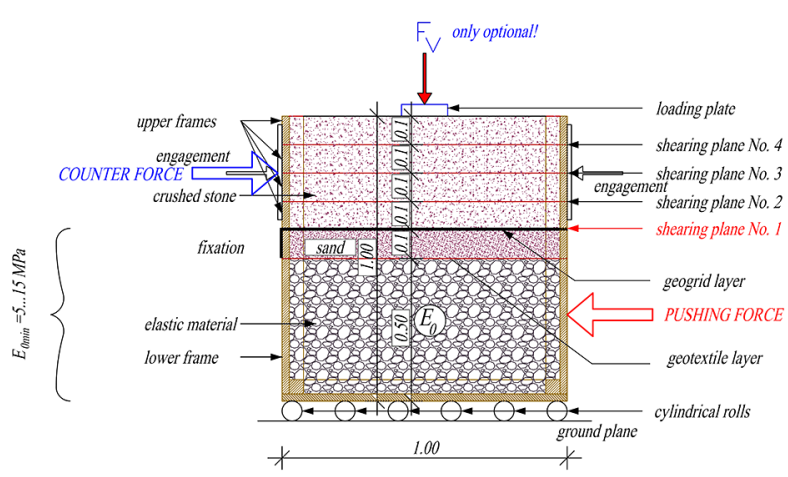

Fig. 2. The conceptual measurement set-up of multi-level shear box, shearing at plane No. 1 [16]

- CGM1 and CGM2;

- M22;

- CSBCG 0/32.

In Figs. 3 and 4, the particle size distribution (PSD) functions of the four examined materials (samples) are shown. Each sample was made of andesite rock. CGM1 and CGM2 samples were prepared with mixing of 5-6 fractions, the M22 and CSBCG $0 / 32$ samples were primer mining products. Each sample is from the quarries of Colas Eszakko Ltd.

It can be seen in Figs. 3 and 4 that neither the M22, nor the CSBCG 0/32 samples do not fit the border lines of PSD of CGM1 and CGM2, respectively.

The PSD curve of the examined CSBCG 0/32 sample sticks out only a little bit at the lower border line of the CGM2 material; with a small modification it could be adequate for this requirement. The PSD curve of the M22 sample hardly meets the CGM1's requirement, the main part of the PSD curve sticks out the lower border line.

The Colas Eszakko Ltd. prepared an adequate quantity of samples for all the laboratory tests. These amounts were approximately $1 \mathrm{~m}^{3}$ of granular 'mixture' from each product: CGM1, CGM2, M22 and CSBCG, respectively.

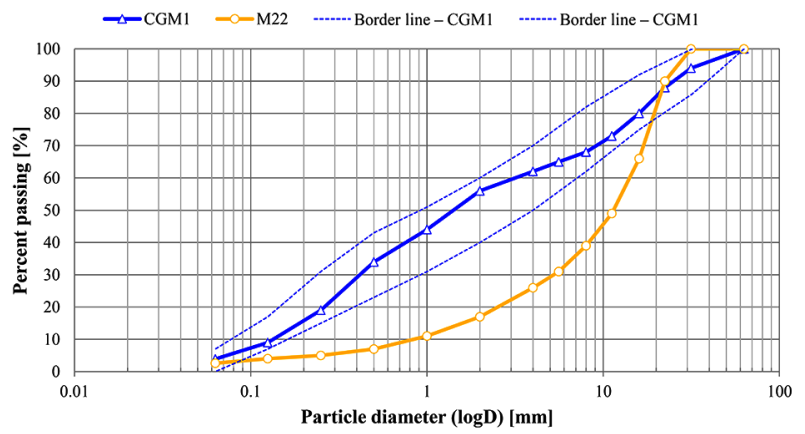

Fig. 3. Particle size distribution of CGM1 and M22 materials (samples) (the border lines are in accordance with [11])

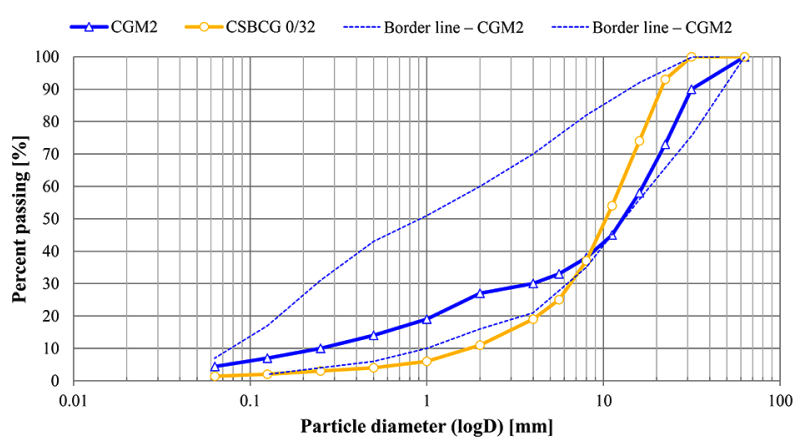

Fig. 4. Particle size distribution of CGM2 and CSBCG 0/32 materials (samples) (the border lines are in accordance with [11])
Results. In this chapter the results of the Proctor tests, load bearing capacity tests (California Bearing Ratio), as well as multi-level shear box tests are interpreted.

Figs. 5 and 6 demonstrate combined diagrams of the Proctor tests and $\mathrm{CBR}$ tests. In these figures the optimal water content $\left(w_{\text {opt }}\right)$ and maximal dry density values $\left(\rho_{d, \max }\right)$ were also represented; they differ between 5.60 and $9.00 \%$, as well as between 1.957 and $2.063 \mathrm{~g} / \mathrm{cm}^{3}$, respectively. The figures contain the so called saturation lines $(S r)$ with different saturation levels (mainly between 0.48 and 1.0 ). $S r=1.0$ means the totally saturated stage.

Analyzing the data of CBR tests with different water content values, we can state the followings:

- while the water content of mixtures of CGM1 and CGM2 increased from 5.0 to $9.0 \%$, their CBR value decreases to $10-$ $15 \%$ of their initial load bearing capacity; in case of their water content values being higher than $11.0 \%$, their load bearing capacity fell down to 0 ;

- in case of M22, at $9 \%$ water content stage it had $30 \%$ of the initial CBR value (related to $5 \%$ water content), at $11 \%$ water content the M22 sample resulted in $19 \%$ of the initial CBR value;

- in case of CSBCG $0 / 32$ sample at $7 \%$ water content stage it had $89 \%$ of the initial CBR value (related to $5 \%$ water content), at $9 \%$ water content the CSBCG $0 / 32$ material provided $223 \%$ of the initial CBR value (it was a very unexpected result, but it can be explained by its very stable grain 'skeleton').

In Fig. 7, the results of the multi-level shear box tests are summarized. It has to be mentioned that all of the published results are related to compacted stages. The compaction procedure is detailed in [16]. The depicted values are the average values of the calculated characteristic values from three measurements (basis and two repetitions additionally) related to each sample and each shearing plane. Because of the limited space, the single graphs of vertical load vs. horizontal displacement of the frames during the shear tests are not published, only their usable results.

Based on the results that are shown in Fig. 7, it can be stated that CGM2 sample $(w=9.72 \%)$ ensured the absolute maximum

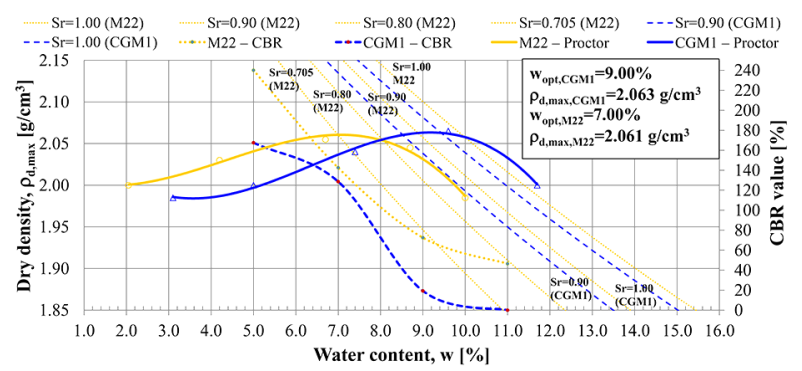

Fig. 5. Results of Proctor tests and CBR tests in case of CGM1 and M22 samples, supplemented by saturation lines with different saturation stages $\left(S_{r}\right)$

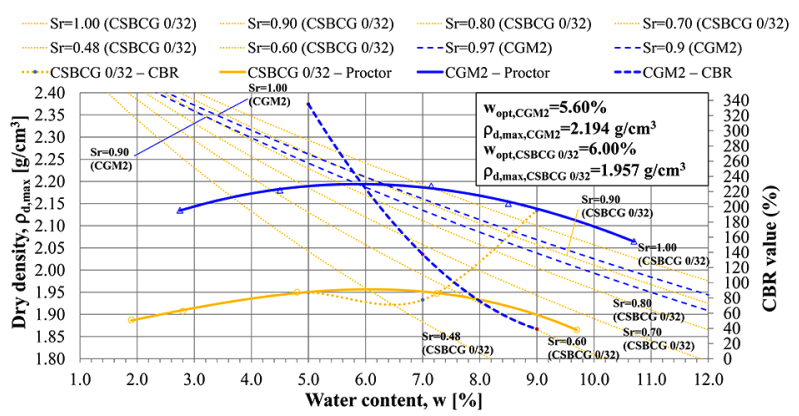

Fig. 6. Results of Proctor tests and CBR tests in case of CGM2 and CSBCG 0/32 samples, supplemented by saturation lines with different saturation stages $\left(S_{\imath}\right)$ 


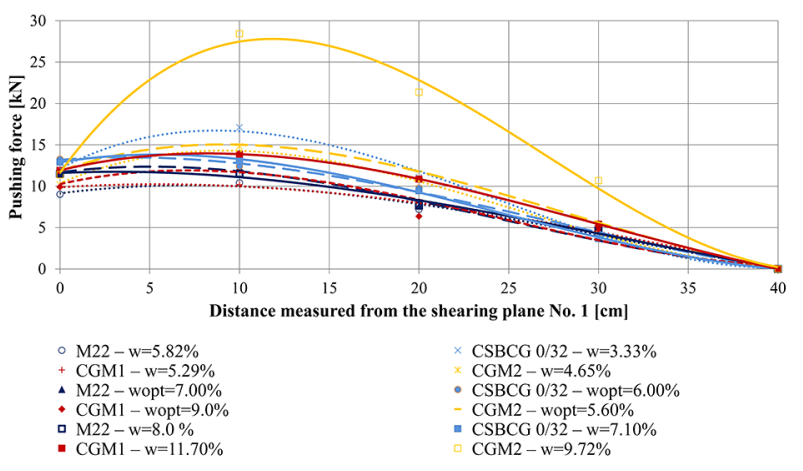

Fig. 7. Results of multi-level shear box tests

inner shear resistance (i.e. the pushing force value in Fig. 7): $28.44 \mathrm{kN}$ on the shearing plane No. $2(10 \mathrm{~cm}$ higher than the lowest considered shearing plane), among all of the tested samples. The other result lines can be hardy compared with each other. Only one relevant statement can be drawn, the maximal inner shear force can be measured in the shearing plane No. 2 related to each sample and each water content value.

Because of the fact that the results cannot be assessed with adequate method, the author decided to define and calculate an additional parameter based on the results of multi-level shear box tests. This parameter was the integer of the graphs (i. e. the area below the lines/graphs).

Fig. 8 represents the integer of the inner shear resistance graphs as a function of water content of the samples.

The water content values are represented as saturation stages (levels) (Fig. 8); dry stage means the normal water content without mixing additional water (the stage of equilibrium in the laboratory air humidity and temperature); optimal stage means the sample with optimal water content; wet stage is related to a considered water content higher than optimal water content value during the multi-level shear box tests. The exact water content values can be seen in the legend of Fig. 7.

Based on the results that are shown in Fig. 8, the following can be declared:

- in the first approach, the integer of the inner shear resistance graph varies in almost the same interval (279.0$405.2 \mathrm{kN} \cdot \mathrm{cm}$ ), only the CGM2's result line sticks out from this zone in case of $9.72 \%$ water content. This extreme high value can be measured due to the increased pressure of pore water (based on calculations it had more water than the saturated stage);

- the products M22 and CSBCG 0/32 were hardly or less sensible on the variation of water content, whose effect did not strongly appear during the multi-level shear box tests.

Conclusions. The author introduced and summarized his laboratory tests and their results. These tests were Proctor tests, load bearing capacity measurements (as California Bearing Ratio), as well as multi-level shear box tests. Four different granular railway supplementary layers were considered with different water content values. These granular mixtures were

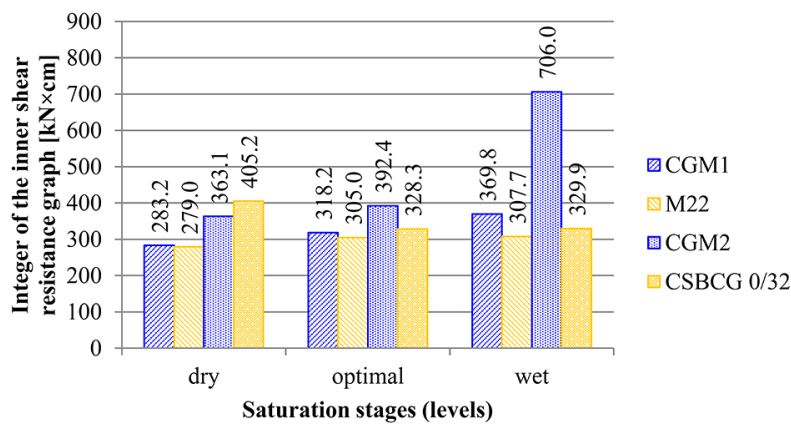

Fig. 8. Integer of the inner shear resistance graph saturation stages (levels) related to all the four considered granular materials the CGM1 and CGM2 products, as well as the M22 and CSBCG 0/32 materials. The first two mixtures are common (standardized) supplementary layers for railway substructure [11]; hence the M22 and CSBCG $0 / 32$ products are mainly applied for road base courses [15, 17].

All the tested samples were produced with the application of the same andesite rock.

The aim of this paper was to investigate and examine the possibility of using M22 and CSBCG 0/32 materials as granular railway supplementary layers because they can be produced more easily due to the fact that they are primer mining products, hence the CGM1 and CGM2 are mixtures. Mainly 5 fractures have to be applied for preparation of CGM1 and CGM2 products. The investigation was executed and made with earlier mentioned laboratory tests.

The article did not have the goal to assess the conformance, adequacy of the CGM1 and CGM2 materials as railway supplementary layers. They have been applied in Germany for many years with adequate results, as well as in Hungary they have a lot of references in the railway projects. It has to be mentioned that in Hungary CGM1 and CGM2 layers were mixed using dolomite material that has hydraulic bonding capability; with the application of dolomite, quite high load bearing capacity values can be obtained during and after the railway constructions. It should be also noted that CGM2 layers can be mixed from old, used, fragmented railway ballast material (with application of other fractions, or crushing of the mentioned degraded particles). It is a commonly used method to build a CGM2 layer on the top of the embankment, while above it a CGM1 layer is installed. The CGM2 layer is important because of the capillary break related to 'sublayers' in the substructure; hence the CGM1 layer is important because of its water sealing property.

Based on the results that were detailed in the previous Chapter 'Results' the author formulated the following conclusions:

- although CGM1 and CGM2 granular mixtures provided relatively low CBR values of at higher water content (7-9$11 \%)$, the inner shear resistance values during multi-level shear box test were average;

- CGM2 sample provided the highest inner shear resistance on the shearing plane No. 2, but it can be explained with the 'oversaturated' stage and the increased pore water pressure;

- M22 and CSBCG 0/32 materials ensured good or very good results; based on the CBR tests they held their quite high load bearing capacity with increasing water content;

- the CSBCG 0/32 product provided extreme high CBR value at $9 \%$ water content;

- M22 and CSBCG 0/32 layers seem to be adequate for installing them as granular railway supplementary layers - but this statement is supported and certified with the executed laboratory tests. It means that water permeability tests, longterm field tests are also recommended and needed.

The author draws the attention to the optimal water content of the CGM1 and CGM2 layers during the construction. His laboratory tests and obtained results proved that water content values that are higher than the optimal ones can cause load bearing capacity problems and installation problems. It is a well-known geotechnical fact, but this attention is related to the very narrow zone between the problematic stage and the optimal water content. These complications were not observed with M22 and CSBCG 0/32 materials; they are not sensible to variation of water content.

The author emphasizes the relevancy of the mineral wealth in every country. Hungary is quite rich in adequate quality minerals that can be applied for civil engineering facilities. The present paper deals with the transport infrastructure, mainly the railway permanent ways and the ballasted tracks. He analyzed the opportunity of the use of road base courses in railway construction projects. The application of M22 and CSBCG $0 / 32$ materials seem to be alternate products such as CGM1 and CGM2 layers after detailed and long-term investigations. 
The following points and tasks can be formulated as further research possibilities:

- financial and economic calculations related to the examined granular supplementary layers (samples) as alternate products;

- performance of additional laboratory tests (e.g. water permeability tests, etc.);

- FE modelling of water seepage related to saturated, unsaturated and 'oversaturated' soils;

- building complex models that can consider the whole railway track, mainly the dynamic effect of loaded superstructure onto the substructure [20].

Acknowledgements. The author would like to thank Colas Eszakko and Colas Hungaria Ltd for their help and support. The author is also grateful for the continuous help of Dr. Katalin Bene, Laszlo Ezsias, Noemi Simon and Erika Juhasz.

\section{References.}

1. Czinder, B., Vásárhelyi, B., \& Török, Á. (2021). Long-term abrasion of rocks assessed by micro-Deval tests and estimation of the abrasion process of rock types based on strength parameters. Engineering Geology, 282, 105996. https://doi.org/10.1016/i.enggeo.2021.105996.

2. Rohrman, A. K., Kashani, H.F., \& Ho, C. L. (2020). Effects of natural abrasion on railroad ballast strength and deformation properties. Construction and Building Materials, 247, 118315. https://doi. org/10.1016/j.conbuildmat.2020.118315.

3. Kurus, K., \& Jaderko-Skubis, K. (2020). Improvement of the effectiveness of greywacke crushing process by applying an impact crusher in quarry for the production of railway ballast. Journal of Sustainable Mining, 19(3), 195-200. https://doi.org/10.46873/2300-3960.1017.

4. Taran, I., \& Klymenko, I. (2017). Analysis of hydrostatic mechanical transmission efficiency in the process of wheeled vehicle braking. Transport Problems, 12 (Special Edition), 45-56. https://doi. org/10.20858/tp.2017.12.se.4.

5. Naumov, V., Taran, I., Litvinova, Y., \& Bauer, M. (2020). Optimizing resources of multimodal transport terminal for material flow service. Sustainability, 12(16), 6545. https://doi.org/10.3390/su12166545 6. Sabraliev, N., Abzhapbarova, A., Nugymanova, G., Taran, I., \& Zhanbirov, Z. (2019). Modern aspects of modeling of transport routes in Kazakhstan. News of the National Academy of Sciences of the Republic of Kazakhstan, Series of Geology and Technical Sciences, 2(434), 6268. https://doi.org/10.32014/2020.2518-1467.36.

7. Novytskyi, O., Taran, I., \& Zhanbirov, Z. (2019). Increasing mine train mass by means of improved efficiency of service braking. E3S Web of Conferences, 123, 01034. https://doi.org/10.1051/e3sconf/201912301034. 8. Tost, M., Ammerer, G., Kot-Niewiadomska, A., \& Gugerell, K. (2021). Mining and Europe's World Heritage Cultural Landscapes. Resources, 10(2), 18. https://doi.org/10.3390/resources 10020018. 9. European Comission (2021, April 8). Integrated Transport OP. Retrieved from https://ec.europa.eu/regional_policy/en/atlas/programmes/2014-2020/hungary/2014hu16m1op003.

10. Deutsche Bahn AG (2013). Erdbauwerke und sonstige geotechnische Bauwerke planen, bauen und instand halten (Richtlinie 836).

11. Hungarian State Railways - MÁV (2020). Vasúti alépitmény tervezése, épitése, karbantartása és felújitása (e-VASUT 02.10.20 D.11). Retrieved from https://www.mosz.co.hu/images/a1644/MAV-2004.pdf.

12. Przybylowicz, M., Sysyn, M., Kovalchuk, V., Nabochenko, O., \& Parneta, B. (2020). Experimental and Theoretical Evaluation of Side Tamping Method for Ballasted Railway Track Maintenance. Transport Problems, 15(3), 93-106. https://doi.org/10.21307/tp-2020-036.

13. Kurhan, M., Kurhan, D., Novik, R., Baydak, S., \& Hmelevs$\mathrm{ka}$, N. (2020). Improvement of the railway track efficiency by minimizing the rail wear in curves. $15^{\text {th }}$ International Scientific and Technical Conference "Problems of the railway transport mechanics" (PRTM 2020), (pp. 1-7). Dnipro, Ukraine, 27-29 May 2020. https://doi. org/10.1088/1757-899X/985/1/012001

14. 100-year-old Hungarian Geological Institute (2021, April 8). Geological map of Hungary. Retrieved from https://gallery.hungaricana. hu/hu/SzerencsKepeslap/1320146/?img $=0$.

15. Magyar Közút Nonprofit Zrt. (2007). Útpályaszerkezetek kötóanyag nélküli és hidraulikus kötöanyagú alaprétegei. Tervezési elöirások (e-UT 06.03.52; ÚT 2 3.207:2007). Retrieved from https://ume.kozut.hu/ dokumentum/131.

16. Sysyn, M., Nabochenko, O., Kovalchuk, V., Przybyłowicz, M., \& Fischer, S. (2021). Investigation of interlocking effect of crushed stone ballast during dynamic loading. Reports in Mechanical Engineering, 2(1), 65-76. https://doi.org/10.31181/rme200102065s.

17. Magyar Közút Nonprofit Zrt. (2012). Útpályaszerkezetek anyagai és épitéstechnológiája. Retrieved from https://adoc.pub/fvednk-schvabzoltan-kzlekedesert-felels-helyettes-allamtitk.html.

18. Hungarian Standards Institute (2011). Unbound and hydraulically bound mixtures. Part 2: Test methods for laboratory reference density and water content. Proctor compaction (MSZ EN 13286-2:2011). Retrieved from https://ugyintezes.mszt.hu/Publications/Details/650998.

19. Hungarian Standards Institute (2012). Unbound and hydraulically bound mixtures. Part 47: Test method for the determination of California bearing ratio, immediate bearing index and linear swelling (MSZ EN 13286-47:2012). Retrieved from https://ugyintezes.mszt.hu/Publications/Details/154580.

20. Kovalchuk, V., Sysyn, M., Gerber, U., Nabochenko, O., Zarour, J., \& Dehne, S. (2019). Experimental Investigation of the Influence of Train Velocity and Travel Direction on the Dynamic Behavior of Stiff Common Crossings. Facta Universitatis Series: Mechanical Engineerng, 17(3), 345-356. https://doi.org/10.22190/FUME190514042K

\section{Дослідження впливу вмісту води на баластний шар залізничної колії}

\section{С. Фімер}

Університет Сечені Іштвана, кафедра транспортної інфраструктури та водних ресурсів, м. Д’єр, Угорщина, e-mail: fischersz@sze.hu

Мета. Визначити взаємозв'язок між вмістом води у безперервних гранульованих баластних шарах підшпальної основи залізничної колії та їхнім внутрішнім опором зсуву й несучою здатністю.

Методика. Чотири різні «зразки» були виготовлені як стандартні гранульовані вироби з андезиту. Два 3 них $є$ загальним базовим варіантом для будівництва доріг в Угорщині, інші два - загальні залізничні баластні шари. Автором були проведені лабораторні вимірювання (багаторівневі випробування на зрушення), що є достатніми для оцінки внутрішнього опору зсуву. Вимірювання несучої здатності й тести Проктора проводились у лабораторії «Colas Hungaria Ltd». Автор проводив вимірювання з оптимальними значеннями вмісту води в кожній пробі, а також із меншими та більшими значеннями. Це може показати, наскільки даний гранульований матеріал чутливий до зміни рівня вмісту води.

Результати. Було доведено, що гранульовані баластні матеріали, які є стандартизованими продуктами в дорожньому будівництві (як базові шари), також виявляються придатними для залізничного будівництва; вони не настільки чутливі до зміни вмісту води. Це не означає, що два інших баластних матеріли не є достатніми для підшпальної основи залізничної колії, але застосування дорожніх «продуктів» слід розглядати як продукти-замінники.

Наукова новизна. Результати доводять адекватність видобутку гірських порід для будівництва залізничних колій на баласті, а також оптимальне використання мінеральних багатств у кожній країні.

Практична значимість. Отримані результати можуть бути корисними в гірничодобувній галузі та інженерії залізничної інфраструктури. Під час проектних і будівельних процедур слід ураховувати оптимальні значення вмісту води для ущільнення, щоб досягти максимальної компактності (щільності), але, виходячи з результатів, занадто великого вмісту води також слід уникати.

Ключові слова: залізнична колія на баласті, підшпальна основа, гранульований матеріал, внутрішній опір зсуву, несуча здатність

Recommended for publication by Varlaki Peter, Habilitated Doctor/Doctor of Sciences. The manuscript was submitted 15.02.21. 